Article

\title{
Chromosome and Genome Divergence between the Cryptic Eurasian Malaria Vector-Species Anopheles messeae and Anopheles daciae
}

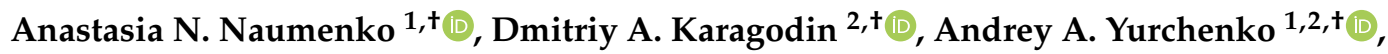 \\ Anton V. Moskaev ${ }^{3,+}$, Olga I. Martin ${ }^{1}$, Elina M. Baricheva ${ }^{4}$, Igor V. Sharakhov ${ }^{1,2,5}{ }^{\mathbb{D} \text {, }}$ \\ Mikhail I. Gordeev ${ }^{3}$ and Maria V. Sharakhova ${ }^{1,2,5, *(D)}$ \\ 1 Department of Entomology and the Fralin Life Science Institute, Virginia Polytechnic and State University, \\ 360 West Campus Drive, Blacksburg, VA 24061, USA; naumenko@vt.edu (A.N.N.); \\ andreyurch@gmail.com (A.A.Y.); oshar@vt.edu (O.I.M.); igor@vt.edu (I.V.S.) \\ 2 Laboratory of Evolutionary Genomics of Insects, the Federal Research Center Institute of Cytology and \\ Genetics, Siberian Branch of the Russian Academy of Sciences, 10 Prospekt Lavrentyeva, 630090 Novosibirsk, \\ Russia; karagodin@bionet.nsc.ru \\ 3 Department of General Biology and Ecology, Moscow Regional State University, 10a Radio Street, \\ 105005 Moscow, Russia; av.moskaev@mgou.ru (A.V.M.); gordeev_mikhail@mail.ru (M.I.G.) \\ 4 Laboratory of Cell Differentiation Mechanisms, the Federal Research Center Institute of Cytology and \\ Genetics, Siberian Branch of the Russian Academy of Sciences, 10 Prospekt Lavrentyeva, \\ 630090 Novosibirsk, Russia; barich@bionet.nsc.ru \\ 5 Laboratory of Ecology, Genetics and Environment Protection, Tomsk State University, 36 Lenina Street, \\ 634041 Tomsk, Russia \\ * Correspondence: msharakh@vt.edu; Tel.: +1-540-232-8560 \\ + The first four authors equally contributed to the paper.
}

Received: 31 December 2019; Accepted: 2 February 2020; Published: 5 February 2020

\begin{abstract}
Chromosomal inversions are important drivers of genome evolution. The Eurasian malaria vector Anopheles messeae has five polymorphic inversions. A cryptic species, An. daciae, has been discriminated from An. messeae based on five fixed nucleotide substitutions in the internal transcribed spacer 2 (ITS2) of ribosomal DNA. However, the inversion polymorphism in An. daciae and the genome divergence between these species remain unexplored. In this study, we sequenced the ITS2 region and analyzed the inversion frequencies of 289 Anopheles larvae specimens collected from three locations in the Moscow region. Five individual genomes for each of the two species were sequenced. We determined that $A n$. messeae and An. daciae differ from each other by the frequency of polymorphic inversions. Inversion X1 was fixed in An. messeae but polymorphic in An. daciae populations. The genome sequence comparison demonstrated genome-wide divergence between the species, especially pronounced on the inversion-rich X chromosome (mean Fst $=0.331$ ). The frequency of polymorphic autosomal inversions was higher in An. messeae than in An. daciae. We conclude that the $\mathrm{X}$ chromosome inversions play an important role in the genomic differentiation between the species. Our study determined that $A n$. messeae and An. daciae are closely related species with incomplete reproductive isolation.
\end{abstract}

Keywords: malaria mosquitoes; polymorphic inversions; genome; internal transcribed spacer 2

\section{Introduction}

Chromosomal inversions are essential drivers of genome evolution in diploid organisms [1]. When a chromosomal inversion occurs, a piece of the chromosome flips 180 degrees and produces 
a reverse order of the genetic material. As a result, this part of the genome becomes resistant to recombination during meiosis. By capturing different combinations of alleles, inversions have effects on ecological, behavioral, and physiological adaptations of the species to the natural environment [2]. The role of the chromosomal inversions in adaptation and evolution of different Drosophila species has been studied for several decades [3-5]. More recently, genome sequencing and mapping revealed functionally important inversions in the human genome [6-10]. Polymorphic inversions have been shown to be associated with epidemiologically important phenotypes in Afrotropical populations of Anopheles [11-14]. Understanding the population genetics and mechanisms of taxa diversification is extremally important for species that transmit human diseases [15]. Among other malaria mosquitoes, An. messeae Falleroni is one of the most geographically widespread [16] and genetically diverse [17] species of malaria mosquitoes in Eurasia. Distribution of the species extends from Ireland in the West to the Amur river region in the East and from Scandinavia and Yakutia in the North to Iran and Northern China in the South [18]. An. messeae was the primary malaria vector in Russia [19] and now represents a threat to malaria re-emergence in the Northern territories of Eurasia because of global climate change $[20,21]$. This species is susceptible to Plasmodium vivax but not to the tropical P. falciparum malaria parasite [16].

An. messeae was originally described as a subspecies of An. maculipennis within the Anopheles maculipennis complex [22]. According to current systematics, the Maculipennis group of malaria mosquitoes comprises eleven Palearctic species: An. artemievi, An. atroparvus, An. beklemishevi, An. daciae, An. labranchiae, An. maculipennis, An. martinius, An. melanoon, An. messeae, An. persiensis, and $A n$. sacharovi [23]. Species in this group have traditionally been recognized based on the chorion patterns of their eggs [24,25] and the banding patterns of their polytene chromosomes [17,26-29]. Three species-An. artemievi [30], An. persiensis [31], and An. daciae [32]-were identified more recently using nucleotide sequence substitutions in the Internal Transcribed Spacer 2 (ITS2) of the ribosomal DNA (rDNA). An. daciae, collected near the Danube river in Romania, was discriminated from An. messeae based on five fixed nucleotide substitutions in ITS2 and by egg morphology; the eggs of An. daciae are generally darker and smaller and have tubercles that are organized in patches of a slightly different shape [32]. Using the molecular approach, An. daciae was later discovered in Germany [33-35], England and Wales [36], and more recently in Poland [37], the Czech republic, Slovakia [38], and Serbia [39]. In most locations, An. daciae was found to be in sympatry with its cryptic species An. messeae. However, the detailed analysis of the inversion polymorphism in An. daciae and the genetic mechanisms of the genomic diversification of these two species remain largely unexplored.

Five highly polymorphic chromosomal inversions have been described in An. messeae species: X1, $X 2$, and X4 on chromosome X; 2R1 on chromosome 2; 3R1 and 3L1 on different arms of chromosome 3 [40]. A latitude cline was described for the 2R1 inversion where the inverted variant was more abundant in northern populations, suggesting that this inversion could be involved in adaptation to cold temperatures and success in overwintering [41]. The frequencies of the X1 and 3R1 inversions displayed a West-East longitude cline with higher frequencies of the inverted variants found in Eastern populations. The X2 inversion is endemic in Western Siberian populations [40]. Comparison of the inversion polymorphisms among populations also suggested that area-specific biological or behavioral adaptations were likely have occurred [42,43]. Inversion frequencies have been shown to be variable in different water reservoirs located next to each other, suggesting involvement of the inversions in local adaptations at the subpopulation level [44]. Inversion frequencies also varied during the summer period with standard variants more abundant in the middle of the summer [45]. Although, inversion frequencies did not significantly change during the 10-year period from 1972 to 1982 [46], a more recent study conducted over a 40-year period from 1974 to 2014 indicated a significant increase in the standard inversion arrangements and a decrease of the 2R1 variant in populations across the An. messeae range in Russia; these changes correlate with the increase in year-round temperatures [47].

Novikov and Kabanova introduced the idea that combinations of inversions in natural populations of An. messeae represent two distinct chromosomal complexes [48]. The variant $\mathrm{X} 0$ is associated with 2R0, 
3R0, and 3L0, and, alternatively, inverted X1 and X2 tends to associate with 2R1, 3R1, and 3L1 [48-50]. These chromosomal complexes confer differences in female fecundity, viability of imago and larvae, food preferences, rate of development, relationship with predators and parasites, and sensitivity to the toxins of Bacillus thuringiensis subsp. israelensis [43,49,51-55]. Later, Novikov referred to these chromosomal complexes as cryptic genetically isolated forms, named " $A$ " and " $B$ " [56] that, however, have overlapping inversion polymorphisms and cannot be distinguished by any fixed inversion differences. Recent ITS2 sequencing studies demonstrated that form " $\mathrm{A}$ " of An. messeae is synonymous with An. daciae $[57,58]$.

In this study, we characterized chromosome and genomic differentiation of An. messeae and An. daciae in three populations from the Moscow region (Novokosino, Noginsk and Yegoryevsk) in Russia based on ITS2 sequencing and karyotyping of 289 individual mosquitoes. Additionally, whole-genome sequencing of five specimens from each species from one population was also performed to characterize genomic diversity and divergence.

\section{Materials and Methods}

\subsection{Field Collection and Material Preservation}

Three hundred mosquito larvae were collected in the summer of 2016 in three locations of the Moscow region, Russia: Novokosino ( $55^{\circ} 44^{\prime} 02.6^{\prime \prime} \mathrm{N}, 37^{\circ} 50^{\prime} 33.5^{\prime \prime}$ E), Kolyshkino boloto in Noginsk ( $\left.55^{\circ} 53^{\prime} 57.4^{\prime \prime} \mathrm{N}, 38^{\circ} 26^{\prime} 17.9^{\prime \prime} \mathrm{E}\right)$, and the village of Parykino near Yegoryevsk ( $55^{\circ} 17^{\prime} 17.9^{\prime \prime} \mathrm{N}$, $39^{\circ} 22^{\prime} 03.5^{\prime \prime}$ E). Positions of the mosquito breeding sites are shown at the map that was developed using OpenStreetMap data [59] (Figure 1). The Novokosino population is located within the boundaries of Moscow. The ponds were characterized by a high oxygen level $(1.8-4.0 \mathrm{mg} / \mathrm{L})$ and high density of larvae ( 93 and 38 per sq. m., respectively) in Novokosino and Noginsk and by a low oxygen level $(0.8 \mathrm{mg} / \mathrm{L})$ and low density of larvae (25 per sq. m.) in Yegoryevsk. Anopheles larvae were collected by the dipping method and then fixed in Carnoy's solution (1:3 acetic acid: ethanol). Larvae were dissected and each individual mosquito was numbered (Supplementary Table S1). Each larva was divided into two parts: head with thorax and abdomen. These dissected parts were placed into separate tubes for further analysis. Heads with thoraxes were kept in Carnoy's solution and abdomens were placed in $70 \%$ ethanol.

\subsection{Genotyping}

The abdomens from each of the 300 specimens were used for DNA extraction. For individual homogenization, sterile $1.5 \mathrm{~mL}$ tubes were used to prevent the risk of contamination. Genomic DNA was extracted from the specimens using a standard protocol for the Qiagen DNeasy Blood and Tissue Kit (Qiagen, Germantown, MD, USA) with slight modifications. Samples were homogenized in $45 \mu \mathrm{L}$ of extraction buffer with $5 \mu \mathrm{L}$ added Proteinase $\mathrm{K}$ and incubated at $56{ }^{\circ} \mathrm{C}$ overnight. DNA elution was performed in $100 \mu \mathrm{L}$ of water.

ITS2 from rDNA was amplified using the forward universal primer designed by Proft [60] $5^{\prime}$-ATCACTCGGCTCTCGTGGATCG-3' $\left(\mathrm{Tm}=64.5^{\circ} \mathrm{C}\right)$ and the reverse primer used by Novikov [56]: $5^{\prime}$-ATGCTTAAATTTAGGGGGTA- $3^{\prime}\left(\mathrm{Tm}=54.2^{\circ} \mathrm{C}\right)$. This primer combination was chosen based on the longer amplicon length $(613 \mathrm{bp})$ and high rate of PCR success $(100 \%)$. Hot start ImmoMix ${ }^{\mathrm{TM}}$ polymerase reaction mix (Bioline, Taunton, MA, USA) was used for the PCR reaction. The PCR mixture contained 1-2 $\mu \mathrm{L}$ of DNA template (depending on concentration), $1 \mu \mathrm{L}$ of both forward and reverse primers at $10 \mu \mathrm{M}$ concentration, and $10 \mu \mathrm{L}$ of $2 \times$ Immomix reaction-mix. Water was added to the mixture to make $20 \mu \mathrm{L}$ of total volume. Amplification was performed using a thermal cycler (Eppendorf, Hauppauge, NY, USA) with the following programmed parameters: initial denaturation at $95^{\circ} \mathrm{C}$ for $10 \mathrm{~min}$, followed by 35 cycles of $95^{\circ} \mathrm{C}$ for $15 \mathrm{~s}, 55^{\circ} \mathrm{C}$ for $30 \mathrm{~s}$, and $72{ }^{\circ} \mathrm{C}$ for $30 \mathrm{~s}$, and a final extension step at $72{ }^{\circ} \mathrm{C}$ for $5 \mathrm{~min}$. The reaction was then placed on hold at $4{ }^{\circ} \mathrm{C}$. 


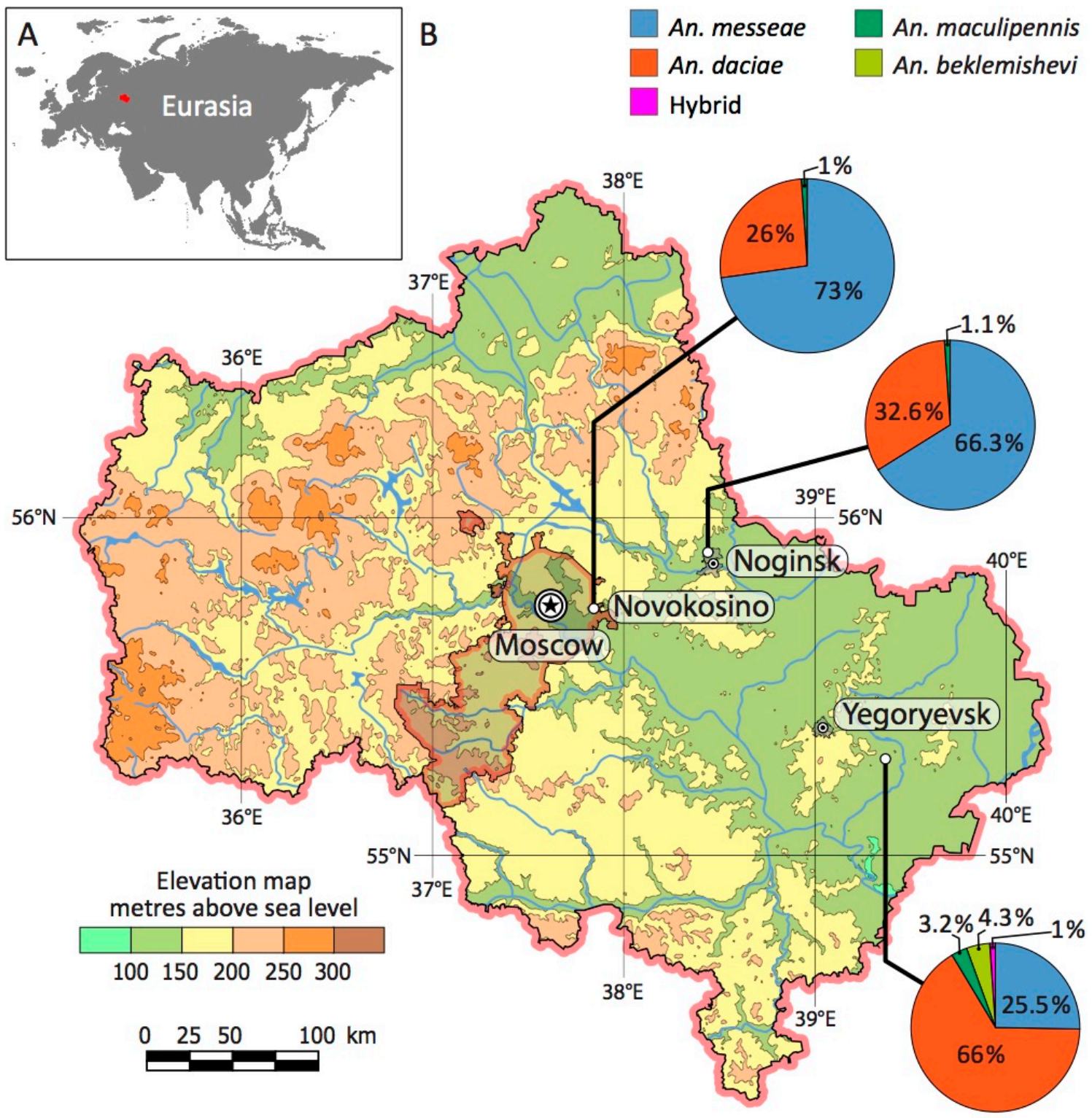

Figure 1. Location of the Moscow region in Eurasia (A) and collection sites of mosquito larvae (B). The ratios of An. messeae, An. daciae, their hybrids, An. maculipennis, and An. beklemishevi are shown as pie charts for each population. The charts show different proportions of the species in three compared populations. The map was developed using OpenStreetMap data [59].

For DNA sequencing, amplicons were visualized using gel electrophoresis and then purified with a Wizard ${ }^{\mathrm{TM}}$ PCR Clean Up kit (Promega, Fitchburg, WI, USA). Concentrations of purified PCR products were measured using a Nanodrop (Thermo Fisher Scientific, Haverhill, MA, USA). PCR products were mixed with either forward or reverse primers and sequenced on the Sanger sequencing platform at the Virginia Biocomplexity Institute. The majority of samples were sequenced with both forward and reverse primers to eliminate the possibility of contamination and to confirm the presence of single-nucleotide polymorphisms (SNPs) on both DNA strands. Samples from Noginsk were sequenced with forward primers only.

A total of 289 specimens were successfully genotyped and further analyzed. ITS2 sequences were analyzed using the SeqScape v 2.5 software (Thermo Fisher Scientific, Haverhill, MA, USA). The ITS2 sequence of An. messeae (Genbank: AY648982) [32] was used as a reference. Base calling was performed using KB basecaller with mixed base identification enabled. The previously described SNPs in positions 211, 215, 217, 412, and 432 distinguish ITS2 sequences of An. measseae from An. daciae and 
the new diagnostic SNP in position 150 were investigated in detail. To verify the appropriateness of the assignment of a nucleotide base in these positions, all diagnostic SNPs were analyzed manually. All ITS2 sequences were submitted to Genbank to obtain accession numbers (Supplementary Table S1).

\subsection{Sequencing and Analysis of Individual Mosquito Genomes}

The individual mosquito genomes of An. daciae (ME36, ME71, ME72, ME78, ME80) and An. messeae (ME3, ME14, ME24, ME25, ME77) were sequenced using Illumina HiSeq 4000 platform in the Fasteris, SA sequencing center. Standard genomic Nano libraries for $2 \times 150$ bp paired-read sequencing were prepared for each sample to obtain 10 million reads aiming at $10 \times$ genome coverage. The raw reads were checked with FastQC software [61] and then trimmed using Trimmomatic v 0.36 [62] to remove bases with poor base quality and the remains of adapters with the following flags: LEADING:24 TRAILING:24 SLIDINGWINDOW:4:24 MINLEN:50. The trimmed reads were mapped to the An. atroparvus genome AatrE2 [63,64] using the BWA mem algorithm [65] with -M flag and sorted with the samtools sort command of the SAMtools package [66]. The single-nucleotide variants (SNVs) were called using samtools mpileup | bcftools call command [67] with the following settings: minimum mapping quality = 55 (-q 55), minimum base quality = 26 (-Q 26), calling only SNVs (-I), and multiallelic calling model (-m). The resulting VCF file was filtered out with VCFtools [68] allowing a minimal phred-scaled SNV quality $=400(-\operatorname{minQ} 400)$, minimal genotype quality $=10(-\operatorname{minGQ}=10)$, no more than $1 \mathrm{missing}$ genotype per SNV (-max-missing-count 1), minimal distance between the SNVs = $10 \mathrm{Kbp}(-\mathrm{thin} 10,000)$ to reduce the number of linked loci, and allow only biallelic SNVs. The scaffold-based coordinates of the SNVs were converted to the chromosome-based coordinates with the Chromosomer tool [69] based on comparison of the cytogenetic maps of An. measseae [40] and An. atroparvus [70].

We calculated the index of population differentiation, Fst [71] between An. messeae and An. daciae using the VCFtools function -weir-fst-pop in the sliding nonoverlapping $5 \mathrm{Kbp}$ windows along the genome. To infer genetic ancestry of the individual genomes, we used ADMIXTURE software [72] to assign fractions of the individual genomes to putative ancestral genetic clusters with $\mathrm{K}=2$ and only autosomal sequences. Principal Component Analysis (PCA) based on the whole genome sequences was carried out with SNPRelate software [73].

\subsection{Karyotyping}

Salivary glands were dissected from the larval thorax for preparations of polytene chromosomes. Chromosome preparations were made by the standard lacto-aceto-orcein method [74]. Polytene chromosomes were visualized using an Eclipse E200 light microscope (Nikon, BioVitrum, Moscow, Russia). Specimens were karyotyped using a standard chromosome map for the salivary glands of An. messeae [40,47,74]. All inversions-X1, X2, X4, 2R1, 3R1, and 3L1-were considered and the karyotype of each specimen was described for the whole chromosomal complement (Supplementary Table S1). We attempted to karyotype a total of 300 specimens (100 samples from each location) but only 289 samples were successfully karyotyped.

\subsection{Statistical Analysis of Chromosomal Inversions}

We used the software GENODIVE [75] to statistically analyze the population architecture of the chromosomal polymorphism. We exploited the AMOVA framework [76,77] to test for significance of the deviations from the Hardy-Weinberg equilibrium with 10k permutations and applied the Bonferroni correction for multiple testing. The pairwise Fst values $[71,76,77]$ between the studied populations were calculated based on 10k permutations using only autosomal inversions and the Bonferroni correction was applied. Finally, we performed the Principal Component Analysis with GENODIVE software using the frequencies of autosomal inversions on the population level to infer and visualize the relationship between the species and its populations. 


\section{Results}

\subsection{Molecular Structure of ITS2 in An. messeae and An. daciae from the Moscow Region}

In this study, we identified An. messeae and An. daciae based on ITS2 sequencing in three populations in Moscow region. As it was reported earlier, the two species differ from each other by five nucleotide substitutions in the ITS2 region of their rDNA sequence [32]. These ITS2 sequences contained the following nucleotides in An. messeae: T, T, C, G, G in positions 211, 215, 217, 412 and 432, respectively. Whereas An. daciae had A, A, T, A, C in the same positions [32]. Here and below, the numbers of the nucleotide positions are given in correspondence to the original sequence submitted under GenBank number AY648982 [32]. In our samples, all 160 of An. messeae had previously described nucleotides (Figure 2A, Table 1). Contrary to most previous descriptions, 119 specimens that we identified as An. daciae had ITS2 sequences with heterogeneous substitutions in the first three positions. We found the following double peaks in sequence chromatograms: $A+T(W), A+T(W)$ and $T+C(Y)$ in positions 211, 215, and 217 but single picks A and C in positions 412 and 432 (Figure 2B, Table 1). Similar sequencing results were obtained for An. messeae and An. daciae from samples in the Novosibirsk region of Russia [58]. In addition to the originally described five substitutions [32], we found another diagnostic nucleotide in position 150 (Figure 2, Table 1). In all our An. messeae specimens, we found a double peak $\mathrm{A}+\mathrm{C}(\mathrm{M})$ in this position, whereas, in the previous report, only nucleotide $\mathrm{C}$ was found in this position in $A n$. messeae [32]. In all our $A n$. daciae specimens, we determined the $C$ nucleotide in position 150 with only two exclusions where a double peak $A+C(M)$ were observed. Based on the sequencing data from 280 samples, we were able to identify only one individual mosquito that we considered a hybrid between $A n$. daciae and An. messeae, where double peaks were presented in all six diagnostic positions (Figure 2C). Thus, we conclude that unique substitutions in positions 412 and 432-G, G for An. messeae and A, C for An. daciae-are the most reliable for the species and hybrid diagnostics.

\subsection{Species Compositions in Moscow Populations}

We collected the larvae of Anopheles mosquitoes from three locations in the Moscow region (Figure 1). The Novokosino larval breeding site was located within the border of the city of Moscow, the Noginsk breeding site was located $36 \mathrm{~km}$ east of Moscow, and the Yegoryevsk breeding site was located in the village of Parykino, which is located $99 \mathrm{~km}$ to the southeast of Moscow. All three populations were located near human settlements in the same landscape zone of the Meshcherskaya Lowland territory. The ponds in Novokosino and Noginsk represented typical breeding sites of Anopheles mosquitoes (Figure 3A,B). The open water surface was exposed to the sun and the abundance of floating vegetation created favorable conditions for the development of mosquito larvae. On the contrary, the larval pond in Yegoryevsk was shaded by trees and contaminated with tree litter (Figure 3C). The three locations differed in the predominant aquatic and near-water plants.

Species composition in the three locations was determined by sequencing ITS2. We found a higher proportion of An. messeae in Novokosino where the percentages of An. messeae to An. daciae were $73 \%$ to $26 \%$, respectively, and in Noginsk where the percentages of An. messeae to An. daciae were $66.3 \%$ and $32.6 \%$, respectively (Figure 1). A different species composition pattern was found in Yegorevsk, with a ratio of $25.5 \%$ to $66 \%$ of $A n$. messeae to $A n$. daciae, respectively. One hybrid mosquito (1\%) was found in Yegorevsk. In addition, four (4.3\%) An. beklemishevi and three (3.2\%) An. maculipennis larvae were identified based on karyotyping [26,78] and ITS2 PCR product length [60] in Yegorevsk and one (1.1\%) An. maculipennis in Noginsk and Novokosino each.

Thus, our study demonstrated that An. messeae dominated in the typical malaria mosquito open, sunny breeding sites of Novokosino and Noginsk, with an increased oxygen content of $1.8-4.0 \mathrm{mg} / \mathrm{L}$ (Figure 3A,B). The density of larvae in these breeding sites was 93 and 38 per sq. m., respectively. An. daciae had the advantage in the unusually shaded breeding site of Yegoryevsk, with high water saprobity and a low oxygen content of $0.8 \mathrm{mg} / \mathrm{L}$ (Figure $3 \mathrm{C}$ ). The density of larvae in this pool was only 
25 per sq. $\mathrm{m}$. It is unclear, if such differentiation is related to the species-specific female oviposition preferences or An. daciae larvae being better adapted to tolerate unfavorable developmental conditions.

\section{A An.messeae}
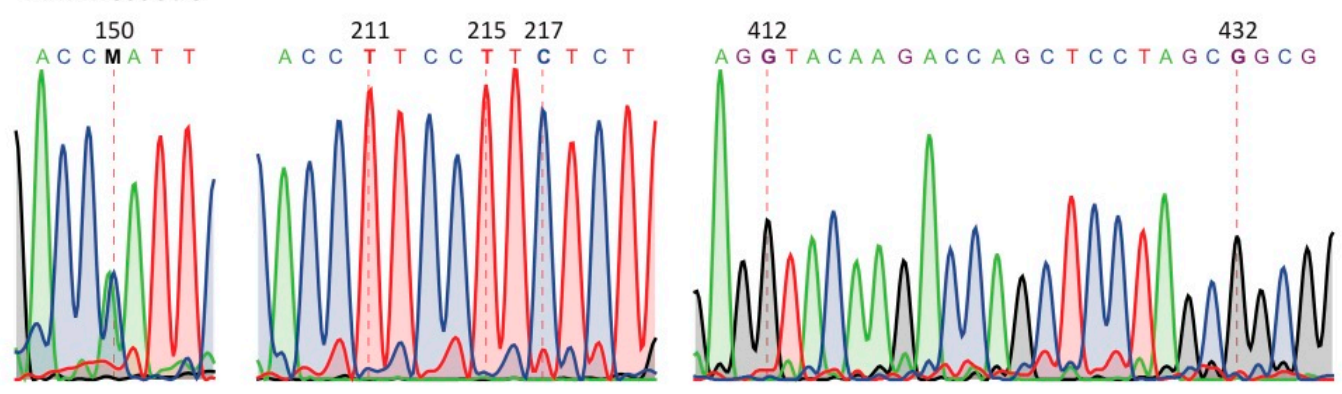

B An. daciae
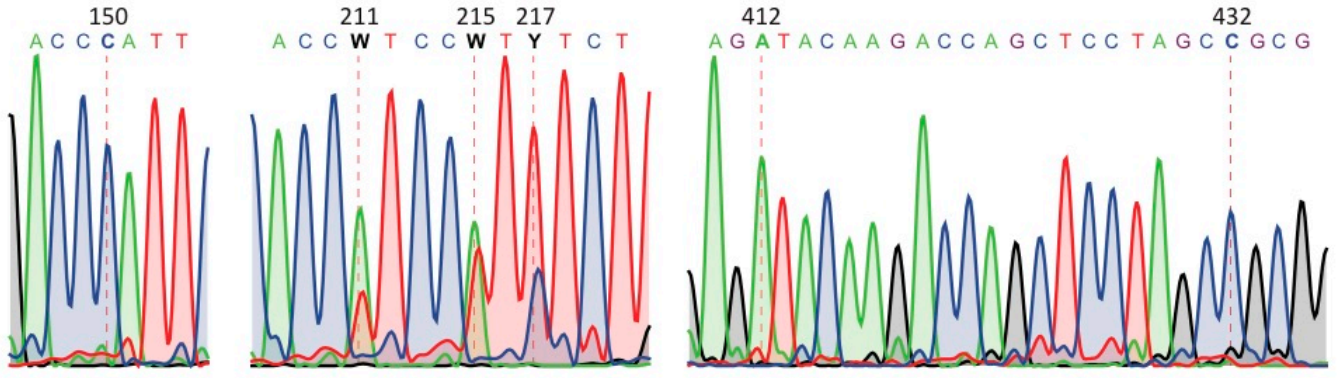

C An. messeae $\times$ An. daciae

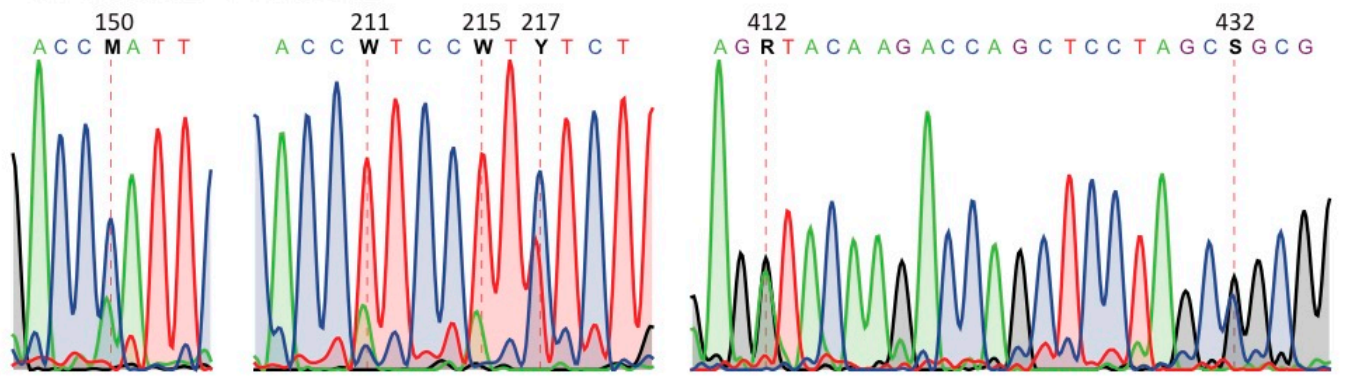

Figure 2. Examples of ITS2 sequence chromatograms for An. messeae (A), An. daciae (B), and their hybrid (C). Dash lines indicate positions of SNPs that distinguish the two species. Chromatograms indicate the presence of double picks in position 150 of An. messeae and in positions 211, 215, and 217 of An. daciae. The specimen with double picks in position 150, 211, 215, 217, 412, and 432 was identified as a hybrid between An. messeae and An. daciae.

Table 1. Variations in ITS2 genotypes of An. messeae and An. daciae from three populations in the Moscow region.

\begin{tabular}{cccccccccc}
\hline Species & \multicolumn{9}{c}{ Genotype } \\
\hline & 150 & 211 & 215 & 217 & 412 & 432 & Novokosino Noginsk & Yegoryevsk \\
\hline An. daciae & $\mathrm{C}$ & $\mathrm{W}(\mathrm{A}+\mathrm{T})$ & $\mathrm{W}(\mathrm{A}+\mathrm{T})$ & $\mathrm{Y}(\mathrm{C}+\mathrm{T})$ & $\mathrm{A}$ & $\mathrm{C}$ & 24 & 31 & 60 \\
\hline & $\mathrm{C}$ & $\mathrm{W}$ & $\mathrm{W}$ & $\mathrm{T}$ & $\mathrm{A}$ & $\mathrm{C}$ & 2 & 0 & 0 \\
\hline & $\mathrm{M}(\mathrm{A}+\mathrm{C})$ & $\mathrm{W}$ & $\mathrm{W}$ & $\mathrm{Y}$ & $\mathrm{A}$ & $\mathrm{C}$ & 0 & 0 & 2 \\
\hline An. messeae & $\mathrm{M}(\mathrm{A}+\mathrm{C})$ & $\mathrm{T}$ & $\mathrm{T}$ & $\mathrm{C}$ & $\mathrm{G}$ & $\mathrm{G}$ & 73 & 63 & 24 \\
\hline Hybrid & $\mathrm{M}$ & $\mathrm{W}$ & $\mathrm{W}$ & $\mathrm{Y}$ & $\mathrm{R}(\mathrm{A}+\mathrm{G})$ & $\mathrm{S}(\mathrm{C}+\mathrm{G})$ & 0 & 0 & 1 \\
\hline Total & & & & & & & 99 & 94 & 87 \\
\hline
\end{tabular}



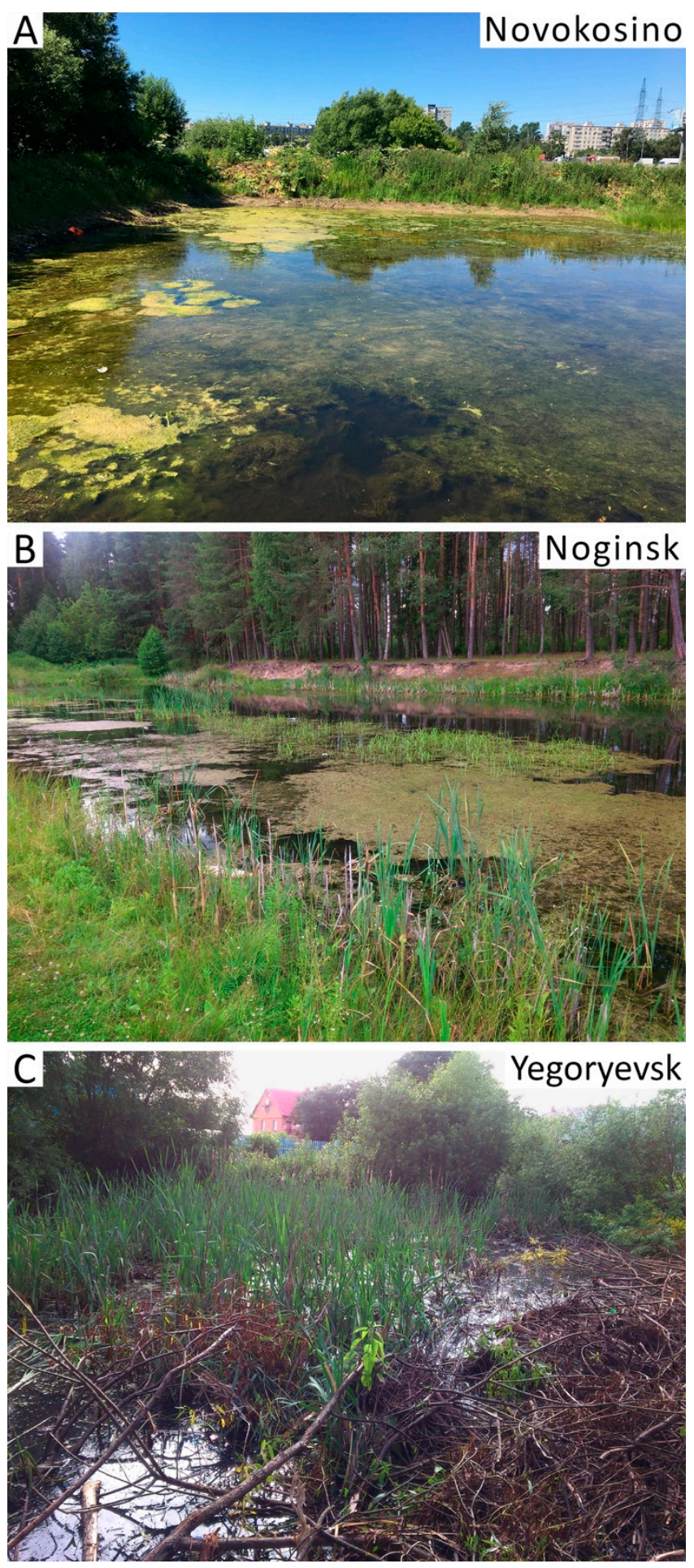

Figure 3. Mosquito breeding sites in Novoskosino (A), Noginsk (B), and Yegoryevsk (C). Ponds in Novokosino and Noginsk are preferred by An. messeae and represent typical for Anopheles sunny larval breeding sites with open water and abundant vegetation. The water reservoir in Yegorevsk, preferred by An. daciae, is shaded and characterized by high water saprobity.

\subsection{Chromosomal Inversions in An. messeae and An. daciae}

Five inversions in four chromosomal arms, X1, X4, 2R1, 3R1, and 3L1, have been previously described in An. messeae in the Moscow region $[30,79,80]$. We analyzed inversion polymorphism in 280 specimens from three locations in Moscow region. The most common inversions in An. messeae 
and An. daciae polytene chromosomes are shown in Figure 4. Inversion X4 is rare and was only found in the Moscow region at a low frequency. The other inversions are common in the populations of An. messeae across the range of its distribution [17]. In our study, each genotyped sample was assigned to a corresponding karyotype (Supplementary Table S1). According to the common nomenclature of inversions in An. messeae, standard arrangements are referred to as 00 variants, inverted as 11 variants, and heterozygotes as 01 or 14 variants. Inversions on the $\mathrm{X}$ chromosome in hemizygous males are referred as 0,1 , and 4 variants.

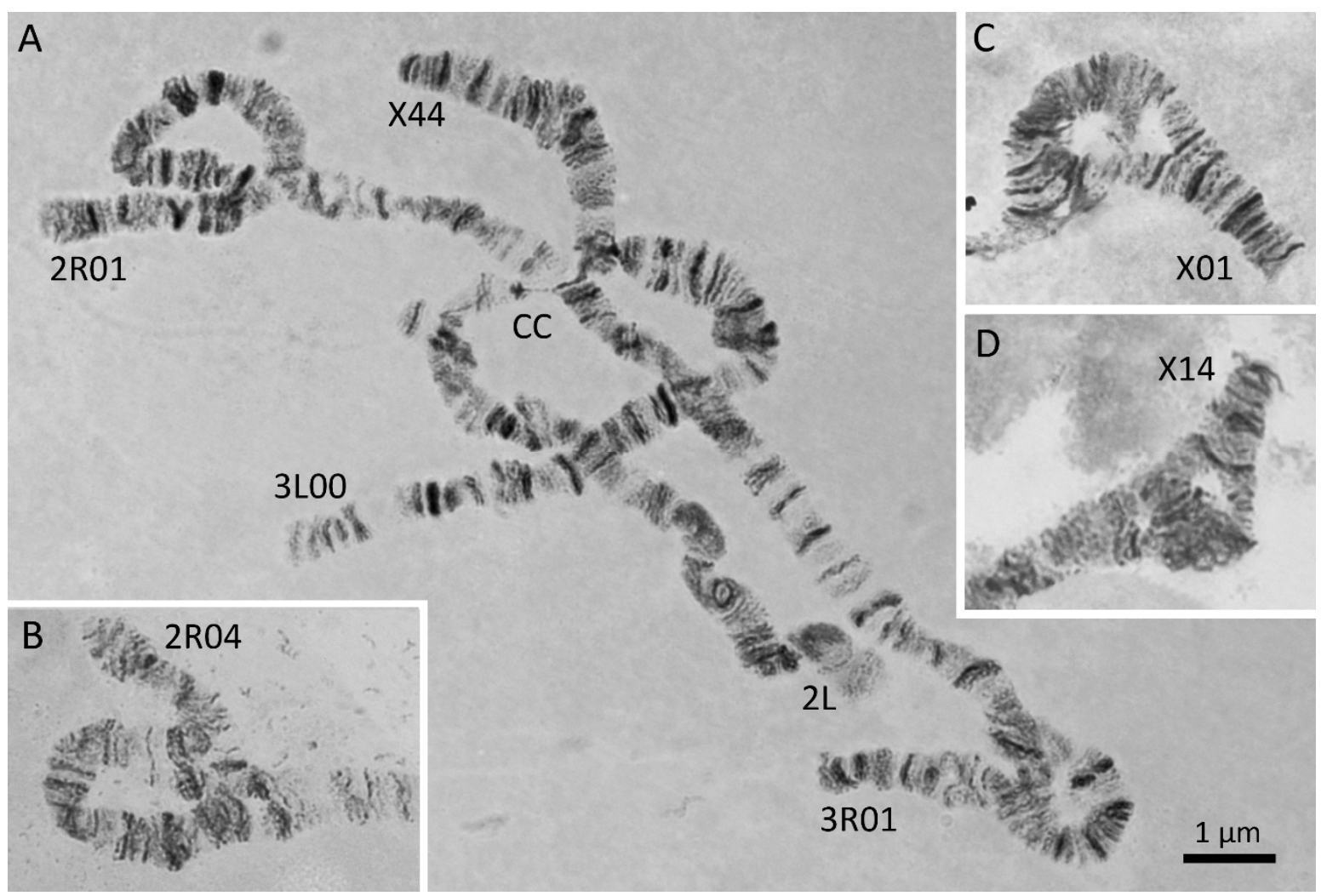

Figure 4. Inversions in polytene chromosomes of An. messeae and An. daciae. The specimens in the Moscow region are characterized by the presence of 4 highly polymorphic inversions $X 1,2 R 1,3 R 1$, and 3L1, and 2 rare endemic inversions $\mathrm{X} 4$ and 2R4. A rare karyotype X44, 2R01, 3R01, and 3L00 in An. messeae is shown on panel A. Another rare inversion heterozygote, 2R04, in An. daciae is shown on panel B. Inversion heterozygotes X01 in An. daciae and X14 in An. messeae are indicated on panels C and D, respectively. CC stands for chromocenter.

The frequencies of the chromosomal inversion variants were calculated for both An. messeae and An. daciae in three populations (Supplementary Table S2, Figure 5). Our analysis demonstrated that frequencies of all chromosomal inversions were significantly different between An. messeae and An. daciae. The most dramatic difference was observed in the $\mathrm{X}$ sex chromosome (Figure 5A). Inversion $\mathrm{X} 1$ was fixed in $A n$. messeae. We found no standard arrangement $\mathrm{X} 0$ in all three populations of An. messeae. In contrast, this arrangement was present in all three An. daciae populations with almost equal frequencies of standard and inverted variants. The endemic inversion $\mathrm{X} 4$ was found only in An. messeae populations in all three locations, although in low frequencies. The $\mathrm{X} 4$ arrangement was observed only in X14 heterozygote females and X4 hemizygote males. Although the inverted autosomal variants $2 \mathrm{R} 1$ and $3 \mathrm{R} 1$ were present in $A n$. daciae, we found significantly higher frequencies of the inverted variants in An. messeae populations (Figure 5B-C). Moreover, inverted variant of the 3L1 inversion were only found in An. messeae in low frequency (Figure 5D). In addition to the previously described chromosomal inversions, we discovered a new inversion, $2 \mathrm{R} 4(7 \mathrm{~A}-11 \mathrm{~A})$, that was found as a 
heterozygote 2R04 in An. daciae from the Yegoryevsk population (Figure 4B, Figure 5B). This unique inversion was found for the first time in only one location. Interestingly, a hybrid between An. daciae and $A n$. messeae carried an unusual karyotype of an $\mathrm{X} 04$ heterozygote of the standard variant $\mathrm{X} 0$, which is typical for An. daciae and the inverted variant X4, which was only observed in An. messeae (ME21 sample in Supplementary Table S1). Overall, our study demonstrated that inversion frequencies were higher on the $\mathrm{X}$ chromosome than on the autosomes in An. daciae, whereas inversion frequencies were higher on autosomes in An. messeae.

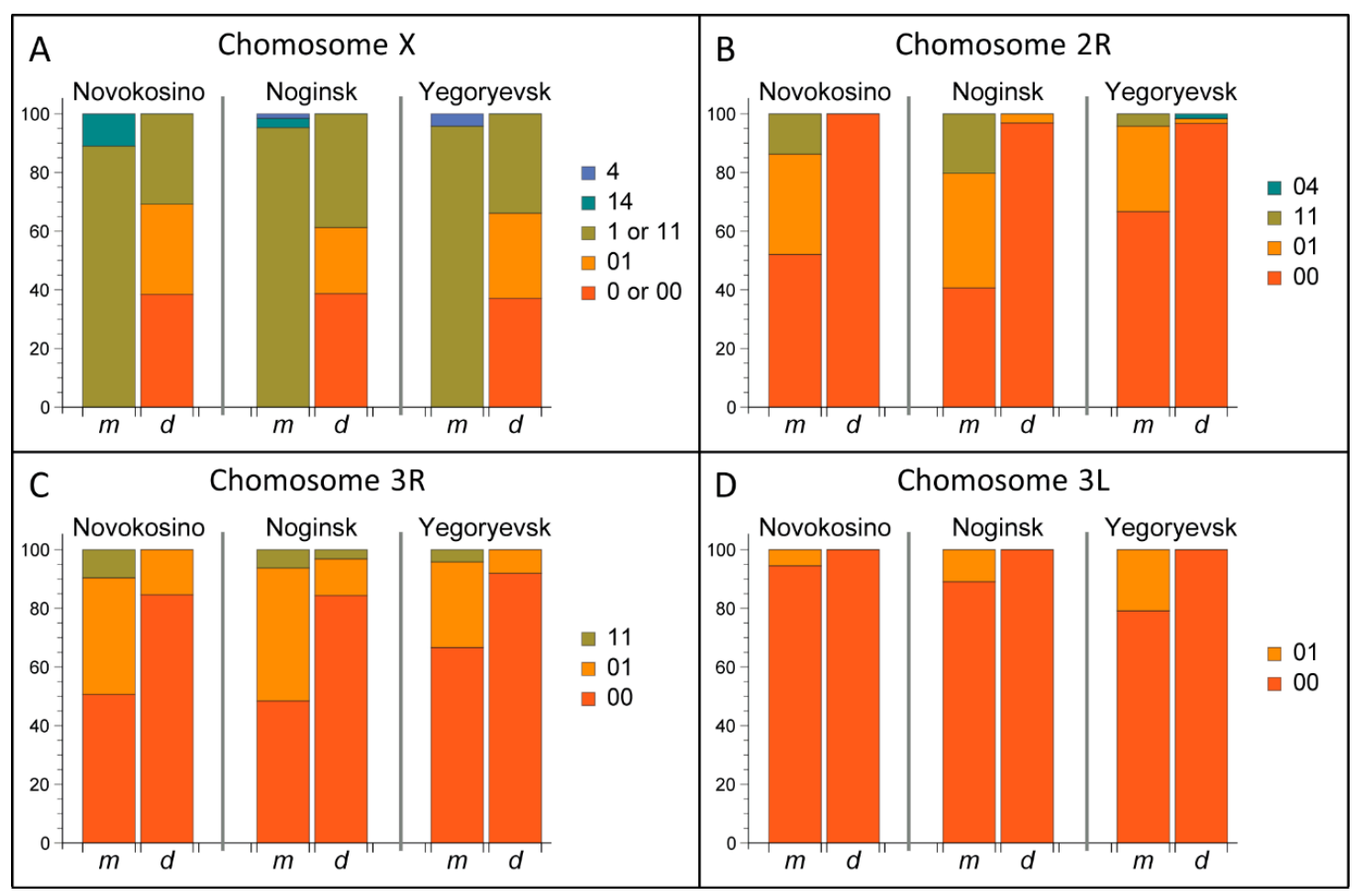

Figure 5. Inversion frequencies in An. messeae and An. daciae from the Novokosino, Noginsk, and Yegoryevsk populations. Frequencies of inversions: X0, X1, and X4 (A); 2R1 and 2R4 (B); 3R1 (C); and 3L1 (D) are shown by charts. Proportions of standard, inverted, and heterozygote arrangements are shown by different colors. Chromosome $\mathrm{X}$ is almost monomorphic in An. messeae but is highly polymorphic in An. daciae in the three Moscow populations. Although all autosomal inversions are present in both species, polymorphism is higher in An. messeae than in An. daciae. Rare inversions, $\mathrm{X} 4$ and 2R4, were found in low frequencies in An. messeae and An. daciae, respectively.

Our statistical analysis demonstrated that the frequencies of homozygotes and heterozygotes within $A n$. messeae and An. daciae samples were in Hardy-Weinberg equilibrium for autosomal inversions but deviated from Hardy-Weinberg equilibrium for sex-linked X-chromosomal inversions in the Noginsk population of An. daciae and in the Yegoryevsk population of both species (Table 2). Pairwise analysis of population differentiation revealed no significant population differentiation within the species ( $\mathrm{Fst}=0.003-0.046$ within An. messeae, Fst $=-0.017-0.01$ within An. daciae, nonsignificant, Table 3), but highly significant Fst values between the two studied species. The interspecies Fst values ranged from 0.076 to 0.28 and were highly significant for a majority of the pairwise comparisons after the Bonferroni correction for multiple testing was applied. The PCA based on the frequency of autosomal inversions only reliably separated the two species by the PC1, accounting for $96.2 \%$ of the total variance (Figure 6). 
Table 2. Statistical significance ( $p$-values) of the deviations from Hardy-Weinberg equilibrium in the studied populations by inversion polymorphism. *-results are significant with $\alpha<0.05$ after applied Bonferroni correction.

\begin{tabular}{llllll}
\hline Population, Species & \multicolumn{1}{c}{$\mathbf{X}$} & & 2R & 3R & \multicolumn{1}{c}{ 3L } \\
\hline Novokosino, An. messeae & 0.817 & 0.071 & 0.433 & 0.958 \\
\hline Novokosino, An. daciae & 0.046 & Monomorphic & 0.878 & Monomorphic \\
\hline Noginsk, An. messeae & 0.051 & 0.111 & 0.302 & 0.838 \\
\hline Noginsk, An. daciae & $0.002 *$ & 1.000 & 0.242 & Monomorphic \\
\hline Yegoryevsk, An. messeae & $0.022 *$ & 0.595 & 0.601 & 0.791 \\
\hline Yegoryevsk, An. daciae & $0.001 *$ & 0.992 & 0.922 & Monomorphic \\
\hline
\end{tabular}

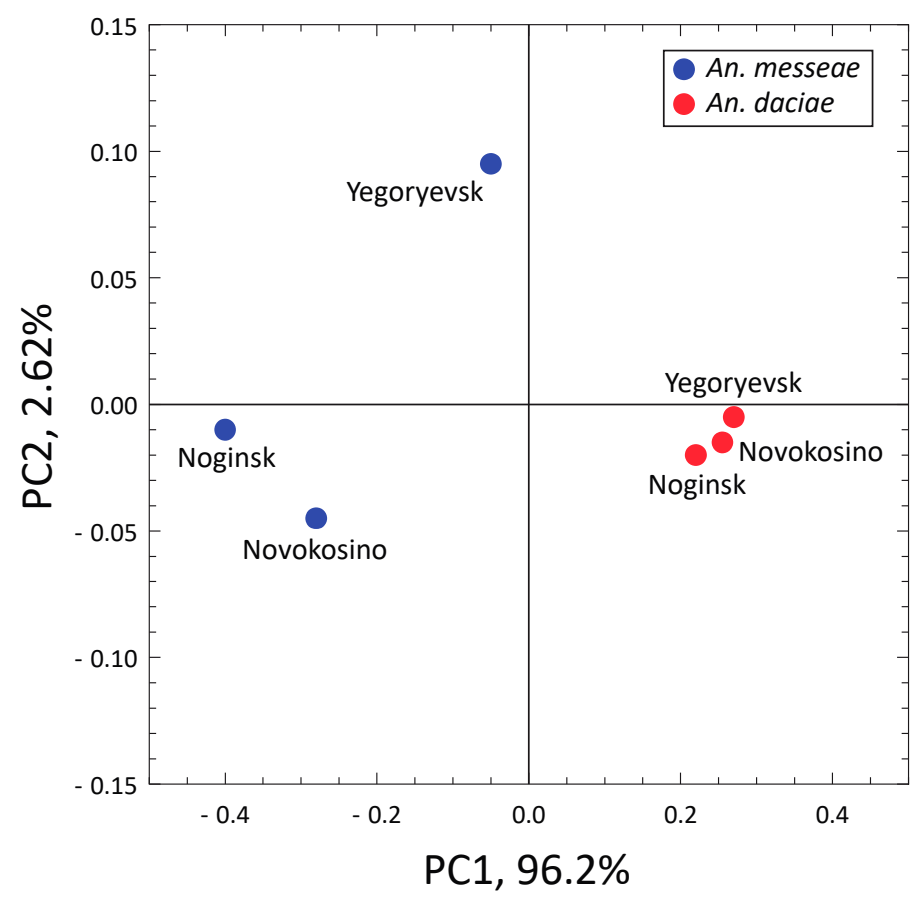

Figure 6. Interpopulation PCA plot based on the frequencies of the autosomal chromosomal inversions in three populations of An. messeae and An. daciae. Species are indicated by different colors. PCA analysis separates An. messeae and An. daciae along the PC1.

Table 3. Pairwise Fst values between the studied populations of An. messeae and An. daciae based on the frequency of autosomal arrangements. *-results are significant with $\alpha<0.05$ after applied Bonferroni correction.

\begin{tabular}{lllllll}
\hline $\begin{array}{l}\text { Population } \\
\text { Species }\end{array}$ & $\begin{array}{l}\text { Novokosino } \\
\text { An.messeae }\end{array}$ & $\begin{array}{l}\text { Novokosino } \\
\text { An. daciae }\end{array}$ & $\begin{array}{l}\text { Noginsk } \\
\text { An.messeae }\end{array}$ & $\begin{array}{l}\text { Noginsk } \\
\text { An.daciae }\end{array}$ & $\begin{array}{l}\text { Yegoryevsk } \\
\text { An.messeae }\end{array}$ & $\begin{array}{l}\text { Yegoryevsk } \\
\text { An.daciae }\end{array}$ \\
\hline $\begin{array}{l}\text { Novokosino } \\
\text { An. messeae }\end{array}$ & - & $0.159 *$ & 0.003 & $0.143^{*}$ & 0.021 & $0.218^{*}$ \\
\hline $\begin{array}{l}\text { Novokosino } \\
\text { An. daciae }\end{array}$ & $0.159 *$ & - & $0.211^{*}$ & -0.017 & $0.095^{*}$ & 0.000 \\
\hline $\begin{array}{l}\text { Noginsk } \\
\text { An. messeae }\end{array}$ & 0.003 & $0.211^{*}$ & - & $0.197^{*}$ & 0.046 & $0.280^{*}$ \\
\hline $\begin{array}{l}\text { Noginsk } \\
\text { An. daciae }\end{array}$ & $0.143^{*}$ & -0.017 & $0.197 *$ & - & 0.076 & 0.010 \\
\hline
\end{tabular}


Table 3. Cont.

\begin{tabular}{lllllll}
\hline $\begin{array}{l}\text { Population } \\
\text { Species }\end{array}$ & $\begin{array}{l}\text { Novokosino } \\
\text { An.messeae }\end{array}$ & $\begin{array}{l}\text { Novokosino } \\
\text { An.daciae }\end{array}$ & $\begin{array}{l}\text { Noginsk } \\
\text { An.messeae }\end{array}$ & $\begin{array}{l}\text { Noginsk } \\
\text { An.daciae }\end{array}$ & $\begin{array}{l}\text { Yegoryevsk } \\
\text { An.messeae }\end{array}$ & $\begin{array}{l}\text { Yegoryevsk } \\
\text { An.daciae }\end{array}$ \\
\hline $\begin{array}{l}\text { Yegoryevsk } \\
\text { An. messeae }\end{array}$ & 0.021 & $0.095^{*}$ & 0.046 & 0.076 & - & $0.164^{*}$ \\
\hline $\begin{array}{l}\text { Yegoryevsk } \\
\text { An. daciae }\end{array}$ & $0.218^{*}$ & 0.000 & $0.280 *$ & 0.010 & $0.164 *$ & - \\
\hline
\end{tabular}

\subsection{Genome Sequence Analysis of An. messeae and An. daciae}

To compare genomic differentiation between the species, we sequenced 10 individual mosquito genomes from the Yegoryevsk population: five individuals each of An. messeae and An. daciae. For each sequenced library, $88.24 \%$ to $90.69 \%$ of the reads were aligned to the An. atroparvus genome as a reference [64]. The average coverage of the sequenced genomes was $20 \times$ and 1,858,004 high-quality SNVs were identified in total after the SNV calling and the filtering step. Analysis of the fixation index (Fst) distribution along the $5 \mathrm{~kb}$ genomic windows revealed small or modest genetic differentiation between the species on autosomes (mean Fst $=0.027$ ), and dramatic increases in the level of genetic differentiation on the $X$ chromosome (mean Fst $=0.331$, Figure 7). A large increase in genomic differentiation is seen in the telomeres, centromeres, and in the middle part of the $\mathrm{X}$ chromosome. The increase in genomic differentiation in the middle part of the chromosomes likely overlaps with the location of the highly polymorphic inversion $\mathrm{X} 1$ and is caused by the low recombination inside the inversions. Some increases in differentiation between the species was also observed in the centromeres of the autosomes, which are regions of low recombination. PCA based on autosomal polymorphisms reliably separated the two species by the PC1 (Figure 8A), accounting for $14.69 \%$ of the total variance. The ADMIXTURE analysis allowed us to separate individuals into two clusters $(K=2)$ based on their species status and on autosomal SNVs, but it also indicated a considerable level of admixture between the species (Figure 8B). Two out of 10 individual mosquitoes were admixed and may represent second or third generation hybrids between the two species. This result suggests that hybridization between the two species is still ongoing in the populations although a larger sample size is needed for a precise estimation of the current gene flow amount.
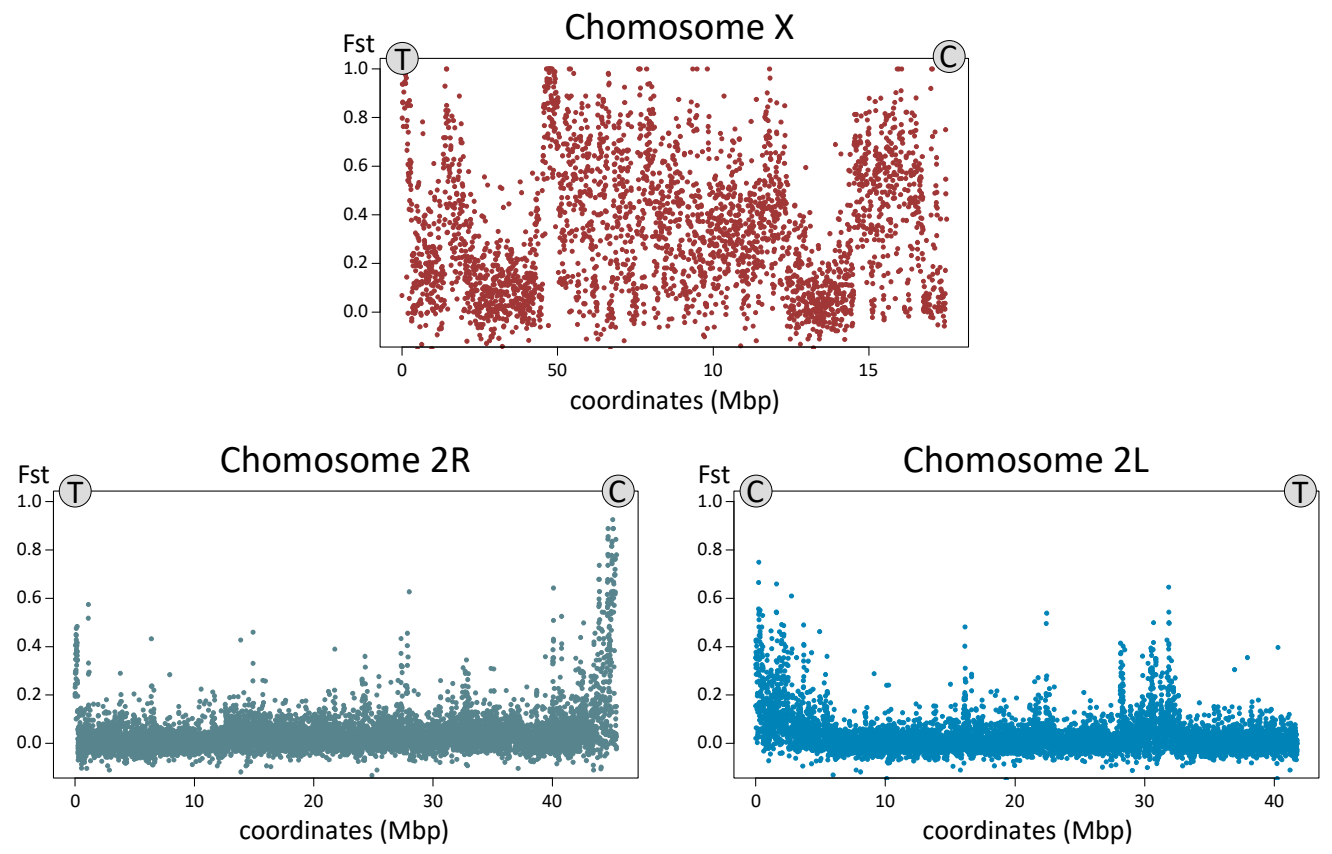

Figure 7. Cont. 

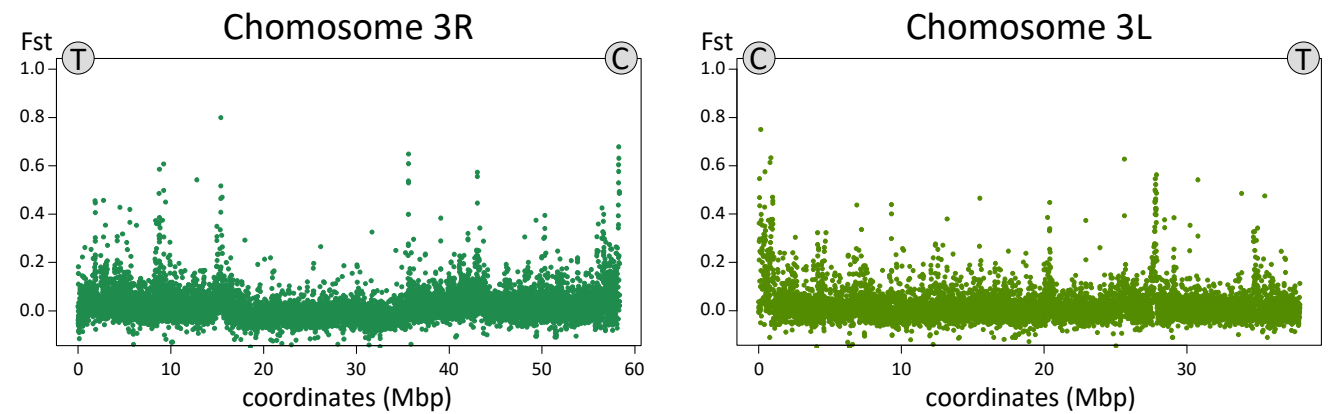

Figure 7. Level of genetic differentiation (Fst) between An. messeae $(\mathrm{n}=5)$ and An. daciae $(\mathrm{n}=5)$ along the chromosomal arms. Each dot represents a $5 \mathrm{~kb}$ window. The $\mathrm{y}$-axis represents Fst values and the $\mathrm{x}$-axis represents the genomic coordinates $(\mathrm{Mbp})$. The $\mathrm{X}$ chromosome demonstrates the highest Fst values while the autosomal arms have a low overall level of differentiation, which is elevated in the centromeric regions. $\mathrm{T}$ and $\mathrm{C}$ stands for telomeres and centromeres, respectively.

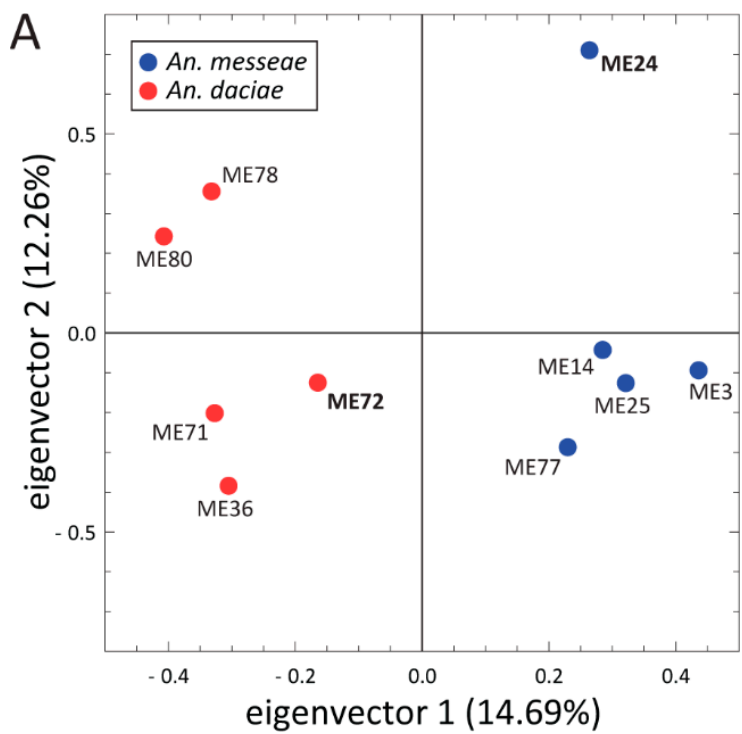

B

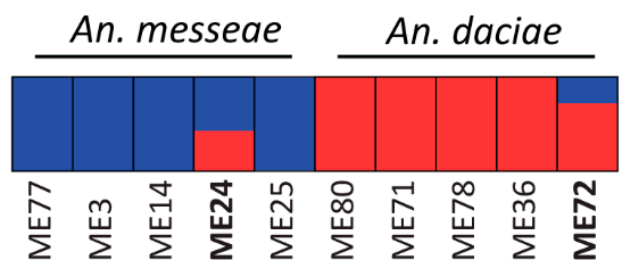

Figure 8. Principal Component Analysis (A) and ADMIXTURE (B) plots based on the autosomal SNVs of the whole genomes of An. messeae and An. daciae. Species are shown by different colors. PCA (A) reliably differentiates two species by the PC1. Each bar (B) represents the proportion of ancestral species in a given individual. Two admixed individuals (shown in bold) were identified.

\section{Discussion}

\subsection{Chromosomal Inversions Differentiate An. messeae and An. daciae}

Our study demonstrated chromosomal differentiation between An. messeae and An. daciae that is more pronounced on the $\mathrm{X}$ sex chromosome. Inversion $\mathrm{X} 1$ was found only as a fixed arrangement in An. messeae, whereas it was polymorphic in An. daciae. Another inversion, X4, was only found as a heterozygote or hemizygote states in An. messeae. Although the 2R1 and 3R1 autosomal inversions were found in both species, the frequencies of these inversion were much higher in An. messeae than in 
An. daciae. Inversion 3L1 was found at low frequency only in An. messeae. Rare inversion 2R4 was found as heterozygotes only in An. daciae. These data indicate that An. messeae is a more polymorphic species at the chromosomal level than An. daciae. PCA analyses conducted based on autosomal inversions clearly separated the two species, suggesting the presence of a reproductive barrier between the species.

Chromosomal analysis is considered to be a powerful tool for determining the taxonomic status of a species and for population analyses. Studies conducted in the past using fruit flies and malaria mosquitoes demonstrated that the species often have fixed inversion differences in their chromosomes with rare occurrences of homosequential species [2,11]. For example, fixed chromosomal differences discriminated An. maculipennis and An. messeae [26], and An. sacharovi and An. martinius [27]. Another species from the Maculipennis group, An. beklemishevi, was identified based on multiple fixed chromosome differences [28,29]. Based on the banding pattern of polytene chromosomes, species in the An. gambiae complex have been differentiated by 10 fixed inversions [11]. Five of these inversions are located on the $\mathrm{X}$ chromosome separating species into three groups possessing the compound Xag inversion, the standard $X$ arrangement, and the compound $X b c d$ inversion [81]. Intensive studies of inversion polymorphism within the major malaria vector An. gambiae identified five chromosomal forms: Bamako, Savanna, Mopti, Forest, and Bissau [82,83]. Interestingly, some of the combinations of chromosomal inversions have never been observed in nature, suggesting the presence of reproductive barriers within the populations. One nucleotide difference in ITS2 led to the discovery of the M and S forms of An. gambiae, which have now been elevated to species status as An. gambiae (former $\mathrm{S}$ form) and $A n$. coluzzii (former M form) [84]. Originally, it was shown that the $\mathrm{M}$ and S molecular forms of An. gambiae correlate with the previously identified chromosomal forms, Mopti and Savanna. However, later studies determined that these inversion patterns did not always correspond to An. gambiae and An. coluzzi across the African continent $[85,86]$. Interestingly, all chromosomal inversions located in the $\mathrm{X}$ sex chromosome in the An. gambiae complex are fixed between the species, suggesting that this chromosome may play an important role in speciation. In contrast, 2 polymorphic inversions were found on the $\mathrm{X}$ chromosome in An. daciae and An. messeae in our study.

\subsection{A Whole-Genome Analysis Determines the Genome-Wide Divergence between An. messeae and An. daciae}

In addition to the cytogenetic analysis, we performed whole-genome sequencing of five specimens of An. messeae and An. daciae from the Yegoryevsk population. Our study identified the whole-genome divergence between the two species. Genomic divergence was most pronounced on the X chromosome and in the pericentromeric areas of the autosomes, suggesting a role of the $X$ chromosome and heterochromatin in species differentiation. At the same time, the level of genomic divergence along the autosomal chromosomal arms was much lower than in chromosome $\mathrm{X}$ indicating that the gene flow is still ongoing in most of the genome or a high level of ancestral shared polymorphism is still present. Although PCA and ADMIXTURE analyses based on autosomal SNVs clearly separated the two species into two clusters, we identified two admixed individuals in the sample of 10 . Together with a single first-generation hybrid identified by ITS2 sequencing, we can conclude that hybridization occurs between $A n$. messeae and An. daciae in the Moscow region. Further genomic studies from different geographic locations are required to estimate hybridization frequencies and the level of genomic differentiation between the two species.

Similar genomic divergence was discovered between An. gambiae and An. coluzzi, formerly the molecular forms $S$ and $M$, respectively, of the An. gambiae complex [87]. As we mentioned above, sequencing of the ITS2 in An. gambiae revealed an intriguing one nucleotide difference in the natural populations suggesting incipient speciation within An. gambiae [87,88]. Despite the ongoing gene flow between the M and S forms [13], the whole-genome comparison based on Affymetrix GeneChip microarrays identified so called "speciation islands" [89], which reside in heterochromatic regions [90] of the genome of An. gambiae. Further whole-genome sequencing of the two forms demonstrated a high level of genomic differentiation across the entire genome [91], which was especially high near 
the centromeres and inside the polymorphic inversions. As a result of these studies, the $M$ and $\mathrm{S}$ forms were elevated to species status and named An. coluzzi and An. gambiae, respectively [84]. Interestingly, the level of the genomic divergence between An. gambiae and An. coluzzii was slightly higher on chromosome $\mathrm{X}$ but not as dramatic as between An. messeae and An. daciae. Such a high level of the genomic divergence on chromosome $X$ could be explained by the inversions located on this chromosome.

The role of the $X$ chromosome in speciation has been shown for various organisms [92]. The large $X$-effect and Haldane's rule are known as two rules of speciation. It has been noticed that the $X$ chromosome has a disproportionally larger effect of on hybrid malfunctions, compared with autosomes [93]. Several theories have been proposed to explain these empirical phenomena. The dominance theory suggests that if alleles driving hybrid dysfunction are recessive and located on the $X$ chromosome, they will be exposed in males mainly affecting the heterogametic sex [94]. Such dominant effects will lead to $X$-linked genes evolving faster than autosome-linked genes according to the faster- $X$ theory [95]. Alternatively, incompatibility between $X$ and $Y$ chromosomes could be due to a mutual imbalance between meiotic drive genes, which are more likely to evolve on sex chromosomes than autosomes [96].

\subsection{An. messeae and An. daciae Differ in Their Ecological Preferences and Behavior}

Understanding species composition and ecological preferences is important for the development and application of any strategy for vector control [16]. The malaria mosquitoes An. daciae and An. messeae occupy regions with temperate oceanic and humid continental climates according to the Eurasian Koppen-Geiger climate classification system [97]. These two species often occur in sympatry [33,35-39,98,99] but their ecological niches do not completely overlap. A recent study conducted in Germany demonstrated that the probability of occurrence of An. messeae had a negative correlation with the maximum temperature of the warmest month and altitude, whereas the probability of occurrence of An. daciae had a positive correlation [98]. In addition, An. messeae negatively correlated with the proportion of variable agricultural land cover and An. daciae was negatively correlated with pasture land cover. As a result, An. messeae demonstrates a decrease in the probability of occurrence from the north to the south of Germany. In contrast, An. daciae has a low probability of occurrence in northwestern and southern Germany. The latter species is also absent in coastal areas of Germany, where An. messeae occurs [35]. These two species show differences in seasonal dynamics as well: An. messeae is more abundant early and late in the season whereas An. daciae is prevalent in the warmest mid-summer months $[35,39,58]$. Both species have differences in blood feeding behavior: females of An. messeae prefer feeding on animals whereas females of An. daciae have opportunistic blood choice behavior and feed on birds, humans, deer, and livestock [36]. This finding suggests that An. daciae may serve as a bridge vector for arboviruses to humans. Moreover, a female of $A n$. daciae infected with the nematode Dirofilaria repens was detected in Germany [34].

Our study provides further insights into possible ecological differentiation of the two species with respect to their preference for larval breeding places. Previous studies demonstrated that An. messeae prefers large clean water reservoirs with a relatively low dissolved ion content [33,39]. In our study, An. messeae also dominated in the typical oxygen-rich $(1.8-4.0 \mathrm{mg} / \mathrm{L})$ anophelogenic breeding sites of Novokosino and Noginsk, with the density of Anopheles larvae being 93 and 38 per sq. m., respectively (Figure 3A,B). An. daciae had an advantage in the atypical breeding place in Yegoryevsk, with high water saprobity, low oxygen content $(0.8 \mathrm{mg} / \mathrm{L})$, and low density of Anopheles larvae (25 per sq. m.). We conclude that the survival optimum for both species, An. daciae and An. messeae, is in the zone of temperate deciduous and mixed forests. There is a sufficient number of favorable biotopes with abundant aquatic vegetation for joint development of both species in the temperate zone. Ecological specialization of sibling species becomes obvious with deviations from the optimum, up to the competitive exclusion of one of the species. Such competitive displacement can be observed at the edges of the ranges, in the steppe and southern taiga zones. However, it is obvious that ecological 
preferences and behavioral differences of An. messeae and An. daciae and the details of their geographical distribution in Russia and other Eurasian countries requires further investigation.

\section{Conclusions}

A cytogenetic analysis conducted here demonstrated strong differentiation between An. messeae and $A n$. daciae by polymorphic inversions especially on the $\mathrm{X}$ chromosome. Inversion $\mathrm{X} 1$ was completely fixed in all three populations of $A n$. messeae, whereas frequencies of the inverted and standard arrangements in An. daciae were almost equal in all populations. Although the two most abundant polymorphic autosomal inversions were found in both species, their frequencies were much higher in An. messeae than in An. daciae. The genomic analyses of 10 individual mosquitoes demonstrated a genome-wide differentiation along the chromosomes. The most dramatic genomic differences were found on the inversion-rich sex chromosome $X$, suggesting a role of this chromosome in reproductive isolation between the species. The ADMIXTURE cluster analysis of 10 individual genomes identified two clusters corresponding to An. messeae and An. daciae. The presence of two admixed individuals suggests that hybridization is ongoing between the populations of An. messeae and An. daciae. Overall, our study suggests that chromosome inversions may play important role in diversification of these two species. We demonstrated that An. messeae and An. daciae represent closely related cryptic species with incomplete reproductive isolation that are able to maintain their genome integrity in sympatry despite genetic introgression.

Supplementary Materials: The following are available online at http://www.mdpi.com/2073-4425/11/2/165/s1, Genomic sequencing data are available via NCBI [100] under and following link https://www.ncbi.nlm.nih.gov/ sra/PRJNA554631 and accession number PRJNA554631. Table S1: ITS2 genotypes and inversion karyotypes in three populations of An. messeae in Moscow region, Table S2: Numbers of individuals with standard and inverted chromosomal arrangements in three Moscow populations of An. messeae and An. daciae.

Author Contributions: Conceptualization, M.V.S., M.I.G., and I.V.S.; Data curation, A.N.N., O.I.M., and A.V.M.; Funding acquisition M.V.S. and M.I.G.; Investigation D.A.K., E.M.B., and A.A.Y; Supervision M.V.S., Writing-original draft, A.N.N., D.A.K., A.A.Y., M.I.G., A.V.M., I.V.S., and M.V.S. All authors have read and agreed to the published version of the manuscript.

Funding: DNA sequencing: bioinformatic and statistical analyses were supported by the Russian Science Foundation grant № 19-14-00130 to M.V.S. Mosquito collections as well as cytogenetic analyses were supported by the Russian Foundation of Basic Research grant № 18-04-01117 A to M.I.G.

Acknowledgments: We thank Lyudmila Tega for her help in collecting mosquito larvae and Janet Webster for proofreading the text.

Conflicts of Interest: Authors declare no competing interests.

\section{References}

1. Kirkpatrick, M.; Barton, N. Chromosome inversions, local adaptation and speciation. Genetics 2006, 173, 419-434. [CrossRef] [PubMed]

2. Ayala, F.J.; Coluzzi, M. Chromosome speciation: Humans, Drosophila, and mosquitoes. Proc. Natl. Acad. Sci. USA 2005, 102 (Suppl. 1), 6535-6542. [CrossRef] [PubMed]

3. Krimbas, C.B.; Powell, J.R. Drosophila Inversion Polymorphism; CRC Press: Boca Raton, FL, USA, 1992.

4. Kapun, M.; Fabian, D.K.; Goudet, J.; Flatt, T. Genomic Evidence for Adaptive Inversion Clines in Drosophila melanogaster. Mol. Biol. Evol. 2016, 33, 1317-1336. [CrossRef] [PubMed]

5. Fuller, Z.L.; Haynes, G.D.; Richards, S.; Schaeffer, S.W. Genomics of natural populations: Evolutionary forces that establish and maintain gene arrangements in Drosophila pseudoobscura. Mol. Ecol. 2017, 26, 6539-6562. [CrossRef] [PubMed]

6. Entesarian, M.; Carlsson, B.; Mansouri, M.R.; Stattin, E.L.; Holmberg, E.; Golovleva, I.; Stefansson, H.; Klar, J.; Dahl, N. A chromosome 10 variant with a $12 \mathrm{Mb}$ inversion [inv(10)(q11.22q21.1)] identical by descent and frequent in the Swedish population. Am. J. Med. Genet. Part A 2009, 149, 380-386. [CrossRef] 
7. Drabova, J.; Trkova, M.; Hancarova, M.; Novotna, D.; Hejtmankova, M.; Havlovicova, M.; Sedlacek, Z. A 15 $\mathrm{Mb}$ large paracentric chromosome 21 inversion identified in Czech population through a pair of flanking duplications. Mol. Cytogenet. 2014, 7, 51. [CrossRef]

8. Stefansson, H.; Helgason, A.; Thorleifsson, G.; Steinthorsdottir, V.; Masson, G.; Barnard, J.; Baker, A.; Jonasdottir, A.; Ingason, A.; Gudnadottir, V.G.; et al. A common inversion under selection in Europeans. Nat. Genet. 2005, 37, 129-137. [CrossRef]

9. Gonzalez, J.R.; Caceres, A.; Esko, T.; Cusco, I.; Puig, M.; Esnaola, M.; Reina, J.; Siroux, V.; Bouzigon, E.; Nadif, R.; et al. A common 16p11.2 inversion underlies the joint susceptibility to asthma and obesity. Am. J. Hum. Genet. 2014, 94, 361-372. [CrossRef]

10. Suzuki, T.; Tsurusaki, Y.; Nakashima, M.; Miyake, N.; Saitsu, H.; Takeda, S.; Matsumoto, N. Precise detection of chromosomal translocation or inversion breakpoints by whole-genome sequencing. J. Hum. Genet. 2014, 59, 649-654. [CrossRef]

11. Coluzzi, M.; Sabatini, A.; della Torre, A.; Di Deco, M.A.; Petrarca, V. A polytene chromosome analysis of the Anopheles gambiae species complex. Science 2002, 298, 1415-1418. [CrossRef]

12. Gray, E.M.; Rocca, K.A.; Costantini, C.; Besansky, N.J. Inversion 2La is associated with enhanced desiccation resistance in Anopheles gambiae. Malar. J. 2009, 8, 215. [CrossRef] [PubMed]

13. Lanzaro, G.C.; Toure, Y.T.; Carnahan, J.; Zheng, L.; Dolo, G.; Traore, S.; Petrarca, V.; Vernick, K.D.; Taylor, C.E. Complexities in the genetic structure of Anopheles gambiae populations in west Africa as revealed by microsatellite DNA analysis. Proc. Natl. Acad. Sci. USA 1998, 95, 14260-14265. [CrossRef] [PubMed]

14. Simard, F.; Ayala, D.; Kamdem, G.C.; Pombi, M.; Etouna, J.; Ose, K.; Fotsing, J.M.; Fontenille, D.; Besansky, N.J.; Costantini, C. Ecological niche partitioning between Anopheles gambiae molecular forms in Cameroon: The ecological side of speciation. BMC Ecol. 2009, 9, 17. [CrossRef] [PubMed]

15. Powell, J.R. Genetic Variation in Insect Vectors: Death of Typology? Insects 2018, 9, 139. [CrossRef] [PubMed]

16. Sinka, M.E.; Bangs, M.J.; Manguin, S.; Coetzee, M.; Mbogo, C.M.; Hemingway, J.; Patil, A.P.; Temperley, W.H.; Gething, P.W.; Kabaria, C.W.; et al. The dominant Anopheles vectors of human malaria in Africa, Europe and the Middle East: Occurrence data, distribution maps and bionomic precis. Parasites Vectors 2010, 3, 117. [CrossRef]

17. Stegniy, V.N. Population Genetics and Evolution of Malaria Mosquitoes; Tomsk State University Publisher: Tomsk, Russia, 1991; p. 137.

18. Gornostaeva, R.M.; Danilov, A.V. On distribution of malaria mosquitoes (Diptera, Culicidae: Anopheles) from Maculipennis Complex in Russian territory. Parsitologia 2002, 26, 33-47.

19. Sokolova, M.I.; Snow, K.R. Malaria vectors in European Russia. European Mosquito Bulletin. J. Eur. Mosq. Control Assoc. 2002, 12,1-6.

20. Novikov, Y.M.; Vaulin, O.V. Expansion of Anopheles maculipennis s.s. (Diptera: Culicidae) to northeastern Europe and northwestern Asia: Causes and consequences. Parasites Vectors 2014, 7, 389. [CrossRef]

21. Githeko, A.K.; Lindsay, S.W.; Confalonieri, U.E.; Patz, J.A. Climate change and vector-borne diseases: A regional analysis. Bull. World Health Organ. 2000, 78, 1136-1147.

22. Falleroni, D. Fauna anofelicaitaliana e suo 'habitat' (paludi, risaie, canali). Metodi di lottacontro la malaria. Riv. Malariol. 1926, 5, 553-593.

23. Harbach, R.E. The classification of genus Anopheles (Diptera: Culicidae): A working hypothesis of phylogenetic relationships. Bull. Entomol. Res. 2004, 94, 537-553. [CrossRef] [PubMed]

24. Hackett, L.W.; Missiroli, A. The varieties of Anopheles maculipennis and their relation to the distribution of malaria in Europe. Riv. Malariol. 1935, 14, 45-109.

25. Gutsevich, A.V.; Monchadskii, A.S.; Shtakelberg, A.A. Fauna of the USSR. Diptera. Mosquitoes; Zoological Institute, USSR Academy of Science: Leningard, Russia, 1970.

26. Stegnii, V.N.; Pestryakova, T.S.; Kabanova, V.M. Cytological identification of sibling species of the malaria mosquitoes Anopheles maculipennis and An. messeae. Zool. Zhurnal 1973, 52, 1971-1976.

27. Stegnii, V.N. Revealing of chromosme races in the malaria mosquito Anopheles sacharovi (Diptera, Culicidae). Tsitologia 1976, 18, 1039-1041.

28. Stegnii, V.N.; Kabanova, V.M. Cytoecological study of natural populations of malaria mosquitoes on the USSR territory. 1. Isolation of a new species of Anopheles in Maculipennis complex by the cytodiagnostic method. Med. Parazitol. 1976, 45, 192-198. 
29. Stegniy, V.N.; Kabanova, V.M. Cytoecological study of indigenous populanions of the malaria mosquito in the territory of the USSR. 1. Identification new species of Anopheles in the Maculipennis complex by the cytodiagnostic method. Mosq. Syst. 1978, 10, 1-12.

30. Gordeev, M.I.; Zvantsov, A.B.; Goriacheva, I.I.; Shaikevich, E.V.; Ezhov, M.N. Description of the new species Anopheles artemievi sp.n. (Diptera, Culicidae). Med. Parazitol. 2005, 2005, 4-5.

31. Sedaghat, M.M.; Linton, Y.M.; Oshaghi, M.A.; Vatandoost, H.; Harbach, R.E. The Anopheles maculipennis complex (Diptera: Culicidae) in Iran: Molecular characterization and recognition of a new species. Bull. Entomol. Res. 2003, 93, 527-535. [CrossRef]

32. Nicolescu, G.; Linton, Y.M.; Vladimirescu, A.; Howard, T.M.; Harbach, R.E. Mosquitoes of the Anopheles maculipennis group (Diptera: Culicidae) in Romania, with the discovery and formal recognition of a new species based on molecular and morphological evidence. Bull. Entomol. Res. 2004, 94, 525-535. [CrossRef]

33. Weitzel, T.; Gauch, C.; Becker, N. Identification of Anopheles daciae in Germany through ITS2 sequencing. Parasitol. Res. 2012, 111, 2431-2438. [CrossRef]

34. Kronefeld, M.; Werner, D.; Kampen, H. PCR identification and distribution of Anopheles daciae (Diptera, Culicidae) in Germany. Parasitol. Res. 2014, 113, 2079-2086. [CrossRef] [PubMed]

35. Kampen, H.; Schafer, M.; Zielke, D.E.; Walther, D. The Anopheles maculipennis complex (Diptera: Culicidae) in Germany: An update following recent monitoring activities. Parasitol. Res. 2016, 115, 3281-3294. [CrossRef]

36. Danabalan, R.; Monaghan, M.T.; Ponsonby, D.J.; Linton, Y.M. Occurrence and host preferences of Anopheles maculipennis group mosquitoes in England and Wales. Med. Vet. Entomol. 2014, 28, 169-178. [CrossRef] [PubMed]

37. Rydzanicz, K.; Czulowska, A.; Manz, C.; Jawien, P. First record of Anopheles daciae (Linton, Nicolescu \& Harbach, 2004) in Poland. J. Vector Ecol. 2017, 42, 196-199. [CrossRef] [PubMed]

38. Blazejova, H.; Sebesta, O.; Rettich, F.; Mendel, J.; Cabanova, V.; Miterpakova, M.; Betasova, L.; Pesko, J.; Hubalek, Z.; Kampen, H.; et al. Cryptic species Anopheles daciae (Diptera: Culicidae) found in the Czech Republic and Slovakia. Parasitol. Res. 2018, 117, 315-321. [CrossRef]

39. Kavran, M.; Zgomba, M.; Weitzel, T.; Petric, D.; Manz, C.; Becker, N. Distribution of Anopheles daciae and other Anopheles maculipennis complex species in Serbia. Parasitol. Res. 2018, 117, 3277-3287. [CrossRef]

40. Stegnii, V.N.; Kabanova, V.M.; Novikov Iu, M. Study of the karyotype of the malaria mosquito. Tsitologiia 1976, 18, 760-766.

41. Stegnii, V.N.; Kabanova, V.M.; Novikov, Y.M.; Pleshkova, G.N. Inversion polymorphism in malaria mosquito Anopheles messeae. I. Distribution of the inversions in the species areal. Genetika 1976, 12, 47-55.

42. Gordeev, M.I.; Sibataev, A.K. Cytogenetic and phenotypic variation in central and peripheral populations of the malaria mosquito, Anopheles messeae Fall. (Diptera, Culicidae). Genetika 1996, 32, 1199-1205.

43. Gordeev, M.I.; Bezzhonova, O.V.; Moskaev, A.V. Chromosomal polymorphism in the populations of malaria mosquito Anopheles messeae (Diptera, Culicidae) at the south of Russian Plain. Genetika 2012, 48, 1124-1128.

44. Perevozkin, V.P.; Gordeev, M.I.; Bondarchuk, S.S. Chromosome polymorphism and regularities of the subpopulation organization of malaria mosquitoes Anopheles (Diptera, Culicidae) in biotopes of the Tomsk oblast. Genetika 2009, 45, 478-487. [CrossRef] [PubMed]

45. Kabanova, V.M.; Stegnii, V.N.; Luzhkova, A.G. Seasonal dynamics of inversion polymorphism in a natural population of the malarial mosquito Anopheles messeae (Diptera: Culicidae). Genetika 1973, 9, 78-82. [PubMed]

46. Stegnii, V.N. Inversion polymorphism of the malarial mosquito Anopheles messeae. IV. The stability of the frequency distribution of the inversions by species area. Genetika 1983, 19, 466-473. [PubMed]

47. Stegniy, V.N.; Pishchelko, A.O.; Sibataev, A.K.; Abylkassymova, G. Spatial and temporal variations of the chromosomal inversion frequencies across the range of malaria mosquito Anopheles messeae Fall. (Culicidae) during the 40-year monitoring period. Genetika 2016, 52, 664-671. [CrossRef] [PubMed]

48. Novikov Iu, M.; Kabanova, V.M. Adaptive association of inversions in a natural population of the malaria mosquito Anopheles messeae Fall. Genetika 1979, 15, 1033-1045.

49. Gordeev, M.I.; Stegnii, V.N. Inversion polymorphism in the malaria mosquito Anopheles messeae. VII. Fertility and the population genetics structure of the species. Genetika 1987, 23, 2169-2174.

50. Stegnii, V.N. Inversion polymorphism of the malarial mosquito Anopheles messeae. V. The interaction of different chromosomal inversions in the spatial area. Genetika 1983, 19, 474-482.

51. Gordeev, M.I.; Troshkov, N. Inversion polymorphism of the malaria mosquito Anopheles messeae. IX. Cannibalism in larvae as a selection factor. Genetika 1990, 26, 1597-1603. 
52. Burlak, V.A.; Gordeev, M.I. The effect of infection by the entomopathogenic bacterium Bacillus thuringiensis on the spread of microsporidia in an inversion-polymorphic population of the malarial mosquito Anopheles messeae (Diptera: Culicidae). Parazitologiia 1998, 32, 264-267.

53. Gordeev, M.I.; Perevozkin, V.P. Strategies for selection and stability to asphyxia in larvae of the malaria mosquito Anopheles messeae with various karyotypes. Genetika 1995, 31, 180-184.

54. Gordeev, M.I.; Burlak, V.A. Inversion polymorphism in malaria mosquito Anopheles messeae. Part X. Resistance of larvae with different genotypes to toxins of crystal-forming bacteria Bacillus thuringiensis subsp. israelensis (serovar H14). Genetika 1991, 27, 238-246. [PubMed]

55. Gordeev, M.I.; Burlak, V.A. Inversion polymorphism in the malaria mosquito Anopheles messeae. XI. The group effect of larval infection with Bacillus thuringiensis subsp. israeliensis bacteria. Genetika 1992, 28, 82-88. [PubMed]

56. Novikov Iu, M.; Shevchenko, A.I. Inversion polymorphism and the divergence of two cryptic forms of Anopheles messeae (Diptera, Culicidae) at the level of genomic DNA repeats. Genetika 2001, 37, 915-925.

57. Vaulin, O.V.; Novikov, Y.M. Geographic variability of ITS2 rDNA and COI mtDNA and cryptic species of malaria mosquito Anopheles messeae Fall. (Diptera: Culicidae). Vestn. VOGIS 2010, 14, 546-555.

58. Vaulin, O.V.; Karagodin, D.A.; Zakharov, I.K.; Baricheva, E.M. The dynamics of the species composition of malaria mosquitoes in Siberian populations, detected using restriction analysis. Genetika 2018, 54, 832-842.

59. OpenStreetMap. Available online: https://www.openstreetmap.org/ (accessed on 15 April 2019).

60. Proft, J.; Maier, W.A.; Kampen, H. Identification of six sibling species of the Anopheles maculipennis complex (Diptera: Culicidae) by a polymerase chain reaction assay. Parasitol. Res. 1999, 85, 837-843. [CrossRef] [PubMed]

61. Andrews, S. FastQC: A Quality Control Tools for High Throughput Sequnce Data. 2010. Available online: https://www.bioinformatics.babraham.ac.uk/projects/fastqc/ (accessed on 15 April 2019).

62. Bolger, A.M.; Lohse, M.; Usadel, B. Trimmomatic: A flexible trimmer for Illumina sequence data. Bioinformatics 2014, 30, 2114-2120. [CrossRef]

63. Neafsey, D.E.; Waterhouse, R.M.; Abai, M.R.; Aganezov, S.S.; Alekseyev, M.A.; Allen, J.E.; Amon, J.; Arca, B.; Arensburger, P.; Artemov, G.; et al. Mosquito genomics. Highly evolvable malaria vectors: The genomes of 16 Anopheles mosquitoes. Science 2015, 347, 1258522. [CrossRef]

64. Artemov, G.N.; Bondarenko, S.M.; Naumenko, A.N.; Stegniy, V.N.; Sharakhova, M.V.; Sharakhov, I.V. Partial-arm translocations in evolution of malaria mosquitoes revealed by high-coverage physical mapping of the Anopheles atroparous genome. BMC Genom. 2018, 19, 278. [CrossRef]

65. Li, H.; Durbin, R. Fast and accurate short read alignment with Burrows-Wheeler transform. Bioinformatics 2009, 25, 1754-1760. [CrossRef]

66. Li, H.; Handsaker, B.; Wysoker, A.; Fennell, T.; Ruan, J.; Homer, N.; Marth, G.; Abecasis, G.; Durbin, R.; Genome, S. Project Data Processing, The Sequence Alignment/Map format and SAMtools. Bioinformatics 2009, 25, 2078-2079. [CrossRef]

67. Li, H. A statistical framework for SNP calling, mutation discovery, association mapping and population genetical parameter estimation from sequencing data. Bioinformatics 2011, 27, 2987-2993. [CrossRef]

68. Danecek, P.; Auton, A.; Abecasis, G.; Albers, C.A.; Banks, E.; DePristo, M.A.; Handsaker, R.E.; Lunter, G.; Marth, G.T.; Sherry, S.T.; et al. The variant call format and VCFtools. Bioinformatics 2011, 27, 2156-2158. [CrossRef]

69. Tamazian, G.; Dobrynin, P.; Krasheninnikova, K.; Komissarov, A.; Koepfli, K.P.; O’Brien, S.J. Chromosomer: A reference-based genome arrangement tool for producing draft chromosome sequences. Gigascience 2016, 5, 38. [CrossRef]

70. Artemov, G.N.; Sharakhova, M.V.; Naumenko, A.N.; Karagodin, D.A.; Baricheva, E.M.; Stegniy, V.N.; Sharakhov, I.V. A standard photomap of ovarian nurse cell chromosomes in the European malaria vector Anopheles atroparvus. Med. Vet. Entomol. 2015, 29, 230-237. [CrossRef]

71. Weir, B.S.; Cockerham, C.C. Estimating F-Statistics for the Analysis of Population Structure. Evolution 1984, 38, 1358-1370. [CrossRef]

72. Alexander, D.H.; Novembre, J.; Lange, K. Fast model-based estimation of ancestry in unrelated individuals. Genome Res. 2009, 19, 1655-1664. [CrossRef]

73. Zheng, X.; Levine, D.; Shen, J.; Gogarten, S.M.; Laurie, C.; Weir, B.S. A high-performance computing toolset for relatedness and principal component analysis of SNP data. Bioinformatics 2012, 28, 3326-3328. [CrossRef] 
74. Kabanova, V.M.; Kartashova, N.N.; Stegnii, V.N. Karyological study of natural populations of malarial mosquitoes in the Middle Ob river. I. Characteristics of the karyotype of Anopheles maculipennis messeae. Tsitologiia 1972, 14, 630-636.

75. Meirmans, P.G.; Van Tienderen, P.H. GENOTYPE and GENODIVE: Two programs for the analysis of genetic diversity of asexual organisms. Mol. Ecol. Notes 2004, 4, 792-794. [CrossRef]

76. Excoffier, L.; Smouse, P.E.; Quattro, J.M. Analysis of molecular variance inferred from metric distances among DNA haplotypes: Application to human mitochondrial DNA restriction data. Genetics 1992, 131, 479-491. [PubMed]

77. Michalakis, Y.; Excoffier, L. A generic estimation of population subdivision using distances between alleles with special reference for microsatellite loci. Genetics 1996, 142, 1061-1064. [PubMed]

78. Stegniy, V.N.; Novikov Iu, M.; Kabanova, V.M. Cytogenetic analysis and distribution of Anopheles beklemishevi. Zool. J. 1978, 57, 873-876.

79. Tanygina, E.; Gordeev, M.I.; Moskaev, A.V.; Ganushkina, L.A. The species and karyotype composition of malaria mosquito larvae in different water reservoirs of the city of Moscow. Med. Parazitol. 2014, $29-33$.

80. Gordeev, M.I.; Moskaev, A.V. Chromosomal polymorphism in the populations of malaria mosquito Anopheles messeae (Diptera, Culicidae) in the Volga region. Genetika 2016, 52, 685-690. [CrossRef]

81. Kamali, M.; Xia, A.; Tu, Z.; Sharakhov, I.V. A New Chromosomal Phylogeny Supports the Repeated Origin of Vectorial Capacity in Malaria Mosquitoes of the Anopheles gambiae Complex. PLoS Pathog. 2012, 8, e1002960. [CrossRef]

82. Toure, Y.T. The current state of studies of malaria vectors and the antivectorial campaign in west Africa. Trans. R. Soc. Trop. Med. Hyg. 1989, 83 (Suppl. 39-41).

83. Toure, Y.T.; Petrarca, V.; Traore, S.F.; Coulibaly, A.; Maiga, H.M.; Sankare, O.; Sow, M.; Di Deco, M.A.; Coluzzi, M. Ecological genetic studies in the chromosomal form Mopti of Anopheles gambiae s.str. in Mali, west Africa. Genetica 1994, 94, 213-223. [CrossRef]

84. Coetzee, M.; Hunt, R.H.; Wilkerson, R.; Della Torre, A.; Coulibaly, M.B.; Besansky, N.J. Anopheles coluzzii and Anopheles amharicus, new members of the Anopheles gambiae complex. Zootaxa 2013, 3619, 246-274. [CrossRef] [PubMed]

85. della Torre, A.; Tu, Z.; Petrarca, V. On the distribution and genetic differentiation of Anopheles gambiae s.s. molecular forms. Insect Biochem. Mol. Biol. 2005, 35, 755-769. [CrossRef] [PubMed]

86. Wondji, C.; Frederic, S.; Petrarca, V.; Etang, J.; Santolamazza, F.; Della Torre, A.; Fontenille, D. Species and populations of the Anopheles gambiae complex in Cameroon with special emphasis on chromosomal and molecular forms of Anopheles gambiae s.s. J. Med. Entomol. 2005, 42, 998-1005. [CrossRef] [PubMed]

87. della Torre, A.; Costantini, C.; Besansky, N.J.; Caccone, A.; Petrarca, V.; Powell, J.R.; Coluzzi, M. Speciation within Anopheles gambiae - the glass is half full. Science 2002, 298, 115-117. [CrossRef] [PubMed]

88. Favia, G.; della Torre, A.; Bagayoko, M.; Lanfrancotti, A.; Sagnon, N.; Toure, Y.T.; Coluzzi, M. Molecular identification of sympatric chromosomal forms of Anopheles gambiae and further evidence of their reproductive isolation. Insect Mol. Biol. 1997, 6, 377-383. [CrossRef] [PubMed]

89. Turner, T.L.; Hahn, M.W.; Nuzhdin, S.V. Genomic islands of speciation in Anopheles gambiae. PLoS Biol. 2005, 3, e285. [CrossRef] [PubMed]

90. Sharakhova, M.V.; George, P.; Brusentsova, I.V.; Leman, S.C.; Bailey, J.A.; Smith, C.D.; Sharakhov, I.V. Genome mapping and characterization of the Anopheles gambiae heterochromatin. BMC Genom. 2010, 11, 459. [CrossRef]

91. Lawniczak, M.K.; Emrich, S.J.; Holloway, A.K.; Regier, A.P.; Olson, M.; White, B.; Redmond, S.; Fulton, L.; Appelbaum, E.; Godfrey, J.; et al. Widespread divergence between incipient Anopheles gambiae species revealed by whole genome sequences. Science 2010, 330, 512-514. [CrossRef]

92. Presgraves, D.C. Evaluating genomic signatures of "the large X-effect" during complex speciation. Mol. Ecol. 2018, 27, 3822-3830. [CrossRef]

93. Coyne, J.A.; Orr, H.A. Speciation; Sinauer Associates: Sunderland, MA, USA, 2004; p. xiii. 545p.

94. Turelli, M.; Orr, H.A. The dominance theory of Haldane's rule. Genetics 1995, 140, 389-402.

95. Charlesworth, B.; Coyne, J.A.; Barton, N.H. The relative rates of evolution of sex chromosomes and autosomes. Am. Nat. 1987, 130, 113-146. [CrossRef]

96. Hurst, L.D.; Pomiankowski, A. Causes of sex ratio bias may account for unisexual sterility in hybrids: A new explanation of Haldane's rule and related phenomena. Genetics 1991, 128, 841-858. 
97. Geiger, R. Classification of Climates after W. Koppen; Springer: Berlin/Heidelberg, Germany, 1954; Volume 3. 
98. Luhken, R.; Czajka, C.; Steinke, S.; Jost, H.; Schmidt-Chanasit, J.; Pfitzner, W.; Becker, N.; Kiel, E.; Kruger, A.; Tannich, E. Distribution of individual members of the mosquito Anopheles maculipennis complex in Germany identified by newly developed real-time PCR assays. Med. Vet. Entomol. 2016, 30, 144-154. [CrossRef] [PubMed]

99. Kronefeld, M.; Dittmann, M.; Zielke, D.; Werner, D.; Kampen, H. Molecular confirmation of the occurrence in Germany of Anopheles daciae (Diptera, Culicidae). Parasites Vectors 2012, 5, 250. [CrossRef] [PubMed]

100. NCBI. Available online: https://www.ncbi.nlm.nih.gov/ (accessed on 15 April 2019).

(C) 2020 by the authors. Licensee MDPI, Basel, Switzerland. This article is an open access article distributed under the terms and conditions of the Creative Commons Attribution (CC BY) license (http://creativecommons.org/licenses/by/4.0/). 